DOI 10.15290/cnisk.2018.01.05.08

DR JULITA SITNIEWSKA

orcid.org/0000-0001-5511-3967

Fundacja na Rzecz Inicjatyw Społecznych

\title{
Słownik Biograficzny Kobiet Kultury. Białystok i województwo podlaskie, cz. I, red. Małgorzata Dajnowicz, Marcin Siedlecki, Wiesław Wróbel, ss. 168, ISBN 978-83-946177-1-4 (całość), 978-83-946177-2-1 (cz. I)
}

Słownik Biograficzny Kobiet Kultury. Białystok i województwo podlaskie, cz. I wydany przez Wydawnictwo Humanica i Instytut Studiów Kobiecych jest pierwszą tego typu publikacją poświęconą kobietom związanym $z$ północno-wschodnią Polską mającym wpływ na rozwój życia kulturalnego tego regionu na przestrzeni wieków. Słownik zawiera dwadzieścia biogramów postaci historycznych, opisanych w chronologicznej kolejności. Zaczyna się portretem Aleksandry Wiesiołowskiej żyjącej w XVI i XVII w., kończy zaś na Annie Markowskiej, uczestniczce wydarzeń XX i początków XXI w. Oprócz wspomnianych bohaterek w słowniku uwzględniono następujące postacie: Elżbietę Drużbacką, Annę Paulinę Jabłonowską, Izabelę Branicką, Elizę Orzeszkową, Marię Konopnicka, Józefę Kisielnicka, Annę Staniszewska, Sofię Casanovę (Lutosławska), Stefanię Karpowicz, Jadwigę Ewę Klimkiewicz, Ewelinę Pepłowską, Izabelę Lutosławską (Wolikowska), Marię Kolendo, Irenę Białównę (Biała), Norę Ney, Placydę Bukowska, Hankę Bielicka, Cecylię Piasecka, Annę Markową. Autorami biogramów są Małgorzata Dajnowicz, Marcin Siedlecki i Wiesław Wróbel.

Niniejszy projekt historyczno-biograficzny zasługuje na szczególną uwagę. Pojawił się rok przed 100. rocznica odzyskania niepodległości przez Polskę, a także w rocznicę nadania praw politycznych Polkom. 
Mimo że tematyka przewodnią działań poszczególnych bohaterek słownika była aktywność w sferze kultury, byłyby one niemymi aktorkami wydarzeń kolejnych pokoleń, gdyby nie zmiany społeczno-polityczne XX w., które pozwoliły zaistnieć w sferze publicznej ich biografiom. Słownik jest także jedna $z$ ważnych publikacji zaliczających się do nurtu badań herstory $^{1}$, ukazujących dokonania kobiet w różnych dziedzinach życia, wydobywających na światło dzienne zapomniane lub mało znane portrety niezwykłych kobiet. W czasach egzystencji bohaterek opowieści o historii podejmowano $z$ męskiego punktu widzenia, a przedmiotowy słownik przedstawia historię, która dzieje się dzięki aktywności kobiet. Oprócz inicjatywy Archiwum Historii Kobiet ${ }^{2}$, które zawiera ponad sto biogramów Polek publikowanych online, słownik jest równie istotnym, szczególnie $\mathrm{w}$ regionalnym wymiarze, kompendium wiedzy o działaczkach w sferze kultury, ale nie tylko. Spełnia funkcję informacyjną i upowszechniająca wiedzę o dokonaniach jego bohaterek. Można za Pierre'em Nora powtórzyć, że mamy do czynienia $z$ „dekolonizacja pamięci”, zabraniem głosu przez grupy, które do tej pory były marginalizowane $\mathrm{w}$ interpretowaniu historii. Pojawiła się wielość pamięci i historii. Warto więc dbać o to, by również kobietom udało się zająć na tej liście [dekolonizacji - J.S.] satysfakcjonujace miejsce ${ }^{4}$. Przedmiotowy słownik jest jedna z inicjatyw, które „dekolonizują" pamięć o kobietach. Każdy biogram zawiera słowa kluczowe charakteryzujące bohaterkę, abstrakt w języku angielskim oraz podsumowanie. Dzięki streszczeniom w obcym języku pozycja poszerza krag odbiorców, umiędzynaradawiając biogramy.

Wśród powszechnie znanych kobiet opisanych w słowniku, jak Izabela Branicka, Maria Konopnicka, Eliza Orzeszkowa, Nora Ney czy Hanka Bielicka, pozostałe sa w większości nieznane w szerszym obiegu. Sa to bohaterki życia lokalnego, o których pamięć zapewne pielęgnowana jest w ich małych ojczyznach. W słowniku zaprezentowano przedstawicielki trzech ziem wchodzących w skład obecnego województwa podlaskiego: suwalczanki - Marię Konopnicka, Annę Staniszewską, bohaterki ziemi łomżyńskiej - Józefę Kisielnicką, Ewelinę Pepłowską, Hankę

\footnotetext{
J. Mills, Womenwords: a dictionary of words about woman, 1992, s. 118.

2 Archiwum Historii Kobiet, [online], [Dostęp: 7.07.2018]. Dostępny w World Wide Web: $<$ http://www.herstorie.pl/>.

3 P. Nora, Czas pamięci, „Res Publica Nowa” 2001, nr 7, s. 37-43.

4 E. Kania, Polska zdekolonizowana? "Pamięć o kobietach” i jej wymiary, „Refleksje” 2011, nr 4, s. 61.
} 
Bielicka, a także znane białostoczanki - Izabelę Branicka, Jadwigę Ewę Klimkiewicz czy Irenę Białównę.

Listę osobowości mających wpływ na życie kulturalne Podlasia otwiera Aleksandra Wiesiołowska (około 1580-1645), której przyszło żyć w okresie, kiedy przełamywano stereotypy niższości intelektualnej kobiet, które brały aktywny udział $w$ dysputach teologicznych, a w XVII w. zdobyły w coraz większym zakresie prawo do edukacjī . Jej aktywność skupiała się w sferze fundacji obiektów sakralnych, takich jak kościół i klasztor Brygidek w Grodnie (dzięki niej sporządzono na piśmie reguły życia klasztornego jego mieszkanek). Ostatnią bohaterka jest Anna Markowa (1932-2008) - lublinianka, ale od 1976 r. zwiazana z Białymstokiem. Swoją twórczość literacka rozpoczęła od poezji, idąc przez prozę, teksty piosenek (wykonywane przez gwiazdy muzyki okresu PRL), słuchowiska radiowe, reportaże i felietony. Te dwie osobowości - Aleksandrę Wiesiołowską i Annę Markową - dziela wieki, obyczaje społeczne i kulturowe oraz sytuacja społeczno-polityczna, ale jednoczy jeden cel - chęć działania. W czasach, w których kobiety pozbawione były praw politycznych, ich rola społeczna w kulturze europejskiej ograniczała się do bycia żona i matka, a przestrzeń na rozwój była możliwa jedynie w sferze prywatnej albo duchowej (oddanie się życiu klasztornemu). Nie dawano im praw do swobodnego poruszania się w innych przestrzeniach życia publicznego. Dopiero upadek struktur feudalnych pozwolił na pracę zawodową i możliwość kształcenia się kobiet, a w konsekwencji angażowanie się w działania publiczne. Biografie bohaterek słownika w chronologicznym ciagu historycznym, począwszy od XVI w., na XXI w. skończywszy, przedstawiaja nam powolne emancypowanie się kobiet i sukcesywne zabieranie przez nie głosu w ważnych sprawach kultury, a także w kwestiach społecznych i publicznych.

Słownik biograficzny kobiet kultury. Białystok i województwo podlaskie, cz. I to nowość i debiut wydawniczy w kategorii zbioru biografii kobiet kultury poświęcony regionowi północno-wschodniemu. Pozycja ta jest ważnym kompendium wiedzy informującym o historiach bohaterek znanych i mniej znanych czytelnikom. Jego wydawcy maja intencję kontynuować prace nad kolejnymi biogramami. Warto byłoby oprócz postaci historycznych ując w publikacji współczesne portrety kobiet animujacych kulturalne życie regionu Podlasia. Przeszłość spotkałaby się $z$ teraźniejszością. Zapewne niezmienna w tych spotkaniach byłaby siła działania bohaterek.

5 U. Augustyniak, Historia Polski 1572-1795, Warszawa 2008, s. 320. 


\section{Bibliografia}

\section{Opracowania}

Augustyniak Urszula, Historia Polski 1572-1795, Warszawa : Wydawnictwo Naukowe PWN, 2008, ISBN 9788301178000.

Kania Eliza, Polska zdekolonizowana? „Pamięć o kobietach” i jej wymiary, „Refleksje” 2011, nr 4, s. 51-61, ISSN 2081-8270.

Mills Jane, Womenwords: a dictionary of words about woman, wyd. 1, Longman, 1992, ISBN 0-02-921495-5.

Nora Pierre, Czas pamięci, „Res Publica Nowa” 2001, nr 7, s. 37-43, ISSN 1230-2155.

\section{Zasoby internetowe}

Archiwum Historii Kobiet, [online], [Dostęp: 7.07.2018]. Dostępny w World Wide Web: <http://www.herstorie.pl/>. 